\title{
Bacillus coahuilensis sp. nov., a moderately halophilic species from a desiccation lagoon in the Cuatro Ciénegas Valley in Coahuila, Mexico
}

\author{
Correspondence \\ Valeria Souza \\ souza@servidor.unam.mx
}

\author{
René Cerritos, ${ }^{1}$ Pablo Vinuesa, ${ }^{2}$ Luis E. Eguiarte, ${ }^{1}$ Luis Herrera-Estrella, ${ }^{3}$ \\ Luis D. Alcaraz-Peraza, ${ }^{4}$ Jackeline L. Arvizu-Gómez, ${ }^{4}$ Gabriela Olmedo, ${ }^{4}$ \\ Enrique Ramirez, ${ }^{4}$ Janet L. Siefert ${ }^{5}$ and Valeria Souza ${ }^{1}$ \\ ${ }^{1}$ Departamento de Ecología Evolutiva, Instituto de Ecología, Universidad Nacional Autónoma de \\ México, Apartado Postal 70-275, México D.F. 04510, Mexico \\ ${ }^{2}$ Programa de Ingeniería Genómica, Centro de Ciencias Genómicas, Universidad Nacional \\ Autónoma de México, Apartado postal 565-A, Cuernavaca, Mor. 62210, Mexico \\ ${ }^{3}$ Langebio, Cinvestav, Apartado Postal 629, Irapuato, Gto. 36821, Mexico \\ ${ }^{4}$ Departamento de Ingeniería Genética de Plantas, Cinvestav Unidad Irapuato, Apartado Postal 629, \\ Irapuato, Gto. 36821, Mexico \\ ${ }^{5}$ Department of Statistics, Rice University, Houston, TX 77251, USA
}

\begin{abstract}
A moderately halophilic, Gram-positive and rod-shaped bacterium, strain $\mathrm{m} 4-4^{\top}$, was isolated from a Chihuahuan desert lagoon in Cuatro Ciénegas, Coahuila, Mexico. Strain m4-4 ${ }^{\top}$ was found to grow optimally at $30-37{ }^{\circ} \mathrm{C}, \mathrm{pH} 7.0-8.0$ and $5 \% \mathrm{NaCl}$ and to tolerate from $0.5 \%$ to $10 \%$ $\mathrm{NaCl}$. It was shown to be aerobic. The genomic DNA G $+\mathrm{C}$ content was about $37 \mathrm{~mol} \%$. Strain $\mathrm{m} 4-4^{\top}$ exhibited minimal or no growth on most sugars tested. Its major cellular fatty acids were $\mathrm{C}_{14: 0}, \mathrm{C}_{16: 0}$ and $\mathrm{C}_{18: 1}$. Based on phylogenetic analysis of $16 \mathrm{~S}$ rRNA and recA gene sequences, we observed that the closest relatives of the isolate are moderately halophilic Bacillus species, with 16S rRNA gene sequence similarity ranging from 96.6 to $97.4 \%$ (Bacillus marisflavi, Bacillus aquimaris and Bacillus vietnamensis). Additionally, using genomic data it was determined that the type strain contains a total of nine rRNA operons with three slightly different sequences. On the basis of phenotypic and molecular properties, strain $\mathrm{m} 4-4^{\top}$ represents a novel species within the genus Bacillus, for which the name Bacillus coahuilensis sp. nov. is proposed, with the type strain $\mathrm{m} 4-4^{\top}\left(=\mathrm{NRRL} B-41737^{\top}=\right.$ CECT $\left.7197^{\top}\right)$.
\end{abstract}

A number of halophilic and moderately halotolerant, Gram-positive, endospore-forming aquatic isolates in the genus Bacillus have been described. A large number of them have been isolated from marine environments (Siefert et al., 2000; Yoon et al., 2003, 2004; Noguchi et al., 2004; Yoon \& Oh, 2005; Lee et al., 2006). However, little is known about species inhabiting non-marine, high salinity aquatic environments (Lim et al., 2006; Souza et al.,

GenBank/EMBL/DDBJ accession numbers for the 16S rRNA gene sequences: m4-4 ${ }^{\top}, E F 014450, E F 014451$ and EF014452; and the recA gene sequences: $\mathrm{m} 4-4^{\top}$, EF014455; $B$. marisflavi TF-11, EF014457; B. vietnamensis NRIC 0530, EF014458; B. vietnamensis NRIC 0531 ${ }^{\top}$, EF014459; B. vietnamensis NRIC 0532, EF014460; B. vietnamensis NRIC 0533, EF014461.

Photomicrographs of Bacillus coahuilensis $\mathrm{m} 4-4^{\top}$, a phylogenetic tree of the recA sequences of $m 4-4^{\top}$ and other bacilli and a table showing the fatty acid composition of $m 4-4^{\top}$ are available with the online version of this paper.
2006). In this study, the Bacillus strain $\mathrm{m} 4-4^{\mathrm{T}}$ was isolated in August 2003 from a desiccation lagoon in the Churince system, a hydrological system on the western side of the Cuatro Ciénegas Valley in Coahuila, Mexico $\left(26^{\circ} 50.830^{\prime} \mathrm{N}\right.$, $\left.102^{\circ} 09.335^{\prime} \mathrm{W}\right)$.

Strain $\mathrm{m} 4-4^{\mathrm{T}}$ was analysed using taxonomic and biochemical methods. Two markers were used for phylogenetic reconstruction (16S rRNA and recA gene sequences). Studies have shown that more robust results are obtained when additional markers such as housekeeping genes are used, especially in closely related isolates (Stackebrandt et al., 2002; Zeigler, 2003). We determined the phylogenetic affiliation of the isolate $\mathrm{m} 4-4^{\mathrm{T}}$ by means of $16 \mathrm{~S}$ rRNA gene phylogeny reconstruction and determined its taxonomic status as a representative of a novel species by using a polyphasic approach. The study also included genomic analysis to determine environmental genome size and diversity of ribosomal operons. 
Strain $\mathrm{m} 4-4^{\mathrm{T}}$ was isolated from surface water samples that were taken and placed in sterile flasks. These were subjected to a shock temperature of $80{ }^{\circ} \mathrm{C}$ for 20 min by means of damp heat (Istock et al., 2001). Subsequently, 1:100 and $1: 1000$ dilutions were made. Aliquots $(100 \mu \mathrm{l})$ from each dilution, as well as from the original water samples, were placed in Petri dishes with marine agar 2216 medium (MA; Difco) and incubated at $37{ }^{\circ} \mathrm{C}$ for 2 days. Cultures were purified by subculturing on the same medium and maintained at $-80{ }^{\circ} \mathrm{C}$ in $5 \% \mathrm{MA}$ and $15 \%(\mathrm{w} / \mathrm{v})$ glycerol.

We studied the cell morphology and sporulation process for strain $\mathrm{m} 4-4^{\mathrm{T}}$ using phase-contrast microscopy. Cells were negatively stained with $1 \%(\mathrm{w} / \mathrm{v})$ malachite green and contrasted with $1 \%(\mathrm{w} / \mathrm{v})$ safranine. Characterization of strain $\mathrm{m} 4-4^{\mathrm{T}}$ included the study of cultural, physiological and biochemical parameters. Single carbon source assimilation tests were performed in MA $\left(4 \mathrm{~g} \mathrm{l}^{-1}\right)$, replacing the yeast extract and peptone with the main carbon source. Nitrate reduction was determined as described by Lányí (1987) in the presence and absence of $3 \%(w / v) ~ N a C l$. Growth at different temperatures was measured on MA between 30 and $50{ }^{\circ} \mathrm{C}$. Urease activity was determined as described previously by Cowan \& Steel (1965).

For quantitative analysis of whole-cell fatty acids, strain m4 $-4^{\mathrm{T}}$ was cultivated on MA for 2 days at $37^{\circ} \mathrm{C}$. The whole-cell fatty acid composition was determined by using a gas chromatograph (model 5890; Hewlett Packard) equipped with a capillary column HP-5MS (30 m $\times$ $0.25 \mathrm{~mm}$ i.d.; $0.25 \mu \mathrm{m}$ film thickness) coupled to a mass spectrometer detector (model 5972; Hewlett Packard). Operating conditions were an injection temperature of
$1500{ }^{\circ} \mathrm{C}$ for $3 \mathrm{~min}$, increasing at the rate of $40{ }^{\circ} \mathrm{C} \mathrm{min}^{-1}$ to a final temperature of $3000{ }^{\circ} \mathrm{C}$, which was maintained for $20 \mathrm{~min}$. Helium was used as carrier gas with a constant flow of $1 \mathrm{ml} \mathrm{min}^{-1}$. Fatty acid methyl esters were identified using the mass spectral library search (NIST MS Data Base) distributed by the National Institute of Standards and Technology (NIST).

A combination of Sanger (Nunally, 2005) and 454 Life Sciences sequencing methods (Margulies et al., 2005) were used to sequence the $\mathrm{m} 4-4^{\mathrm{T}}$ genome, as described by Alcaraz et al. (2008). The genome sequencing found nine ribosomal operons; three of them had slight differences, giving sequences $\mathrm{m} 4-4 \mathrm{a}, \mathrm{b}$ and $\mathrm{c}$ (Fig. 1). The $\mathrm{G}+\mathrm{C}$ content was obtained directly by genomic analysis.

The $16 \mathrm{~S}$ rRNA gene was amplified using the $27 \mathrm{~F}$ and $1492 \mathrm{R}$ primers under conditions described previously (Lane, 1991) in $100 \mu \mathrm{l}$ final volume. The recA gene was chosen for sequencing and phylogenetic analysis. Oligonucleotide primers were designed using the recA genes of the complete genomes of Bacillus strains reported in GenBank. These primers extended from position 28 to 48 (5'-GATCGTCARGCAGSCYTWGAT-3') and from position 583 to 602 (5'-TTWCCRACCATAACSCCRAC-3'), yielding a 574 bp product. PCR mixtures $(25 \mu \mathrm{l})$ were prepared with $1 \mathrm{U}$ Taq polymerase (Roche), $2.5 \mathrm{mM} \mathrm{MgCl}_{2}, 1 \mathrm{mM}$ dNTPs, $2 \mu \mathrm{M}$ each recA primer and $1 \mu \mathrm{l}$ DNA (25$100 \mathrm{ng} \mu \mathrm{l}^{-1}$ ). The PCR program was one cycle of initial denaturation at $95{ }^{\circ} \mathrm{C}$ for $5 \mathrm{~min}, 30$ cycles of denaturation at $95{ }^{\circ} \mathrm{C}$ for $30 \mathrm{~s}$, annealing at $45^{\circ} \mathrm{C}$ for $30 \mathrm{~s}$ and extension at $72{ }^{\circ} \mathrm{C}$ for $60 \mathrm{~s}$, and a final extension cycle at $72{ }^{\circ} \mathrm{C}$ for 5 min. PCR products were purified using a gel extraction

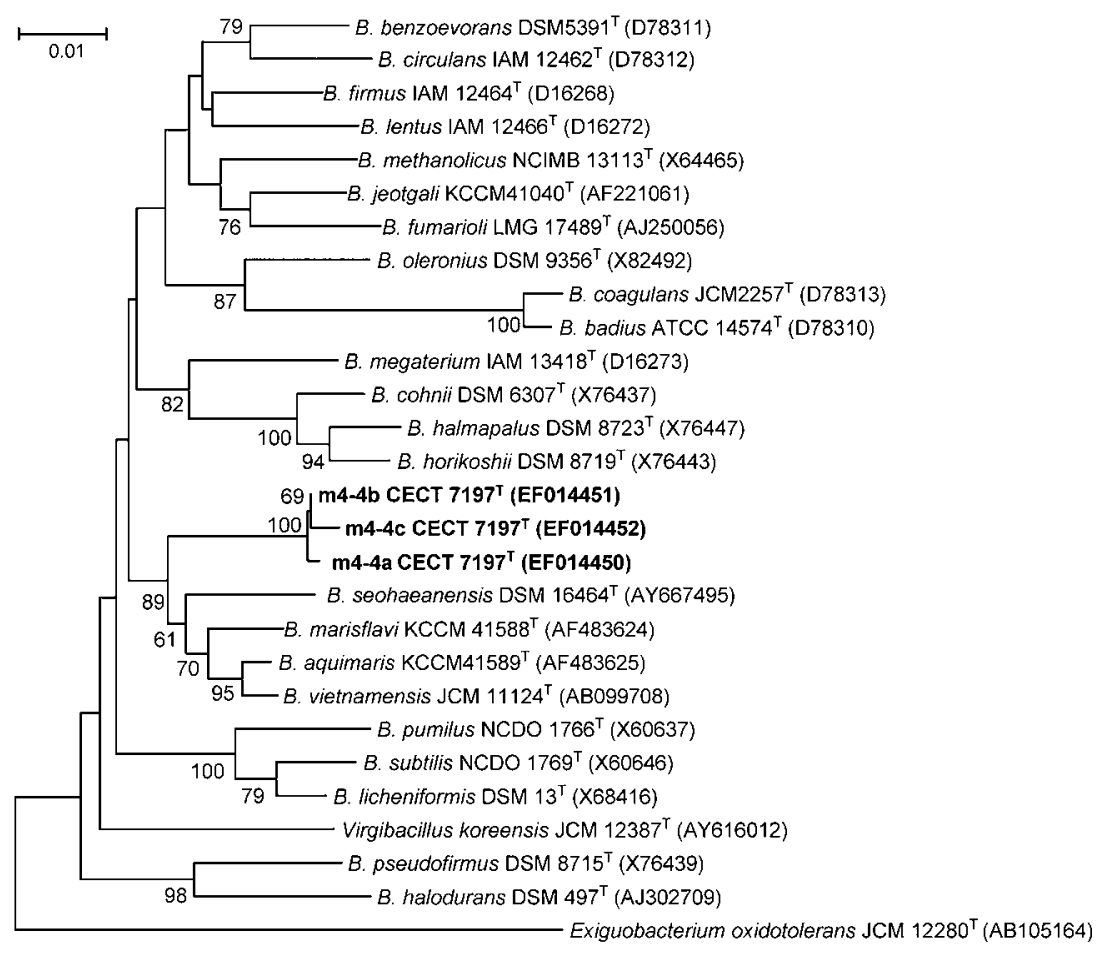

Fig. 1. Unrooted phylogenetic tree using the neighbour-joining method and derived from the analysis of the 16S rRNA gene sequences of strain $\mathrm{m} 4-4^{\top}$ and other representative Bacillus strains. Numbers next to the branches represent bootstrap values expressed as percentages of 2500 replications; only values greater than $70 \%$ are indicated. GenBank accession numbers of sequences are shown in parentheses. Bar, 0.01 substitutions per nucleotide position. 
DNA kit (Qiagen). For the 16S rRNA gene, a fragment of approximately $1400 \mathrm{bp}$ was sequenced with the primer set reported previously (Sacchi et al., 2002). For the recA gene, a $450 \mathrm{bp}$ segment was sequenced from strain m4-4 $4^{\mathrm{T}}, B$. marisflavi $\mathrm{TF}-11^{\mathrm{T}}$ and from four isolates of $B$. vietnamensis (NRIC 0530, 0531 ${ }^{\mathrm{T}}, 0532$ and 0533). The sequencing reaction had a total volume of $15 \mu \mathrm{l}$ consisting of $2 \mu \mathrm{l} \mathrm{Big}$ Dye Terminator sequencing buffer (Applied Biosystems), $1.6 \mu \mathrm{M}$ primer and $5 \mu \mathrm{l}$ purified amplified product. The amplification conditions were as follows: one cycle of 5 min at $95{ }^{\circ} \mathrm{C}$, and 45 cycles of $10 \mathrm{~s}$ at $95{ }^{\circ} \mathrm{C}, 10 \mathrm{~s}$ at $50{ }^{\circ} \mathrm{C}$ and $4 \mathrm{~min}$ at $60^{\circ} \mathrm{C}$. Sequencing was done in a capillary sequencer (ABI-Avant 100). Sequences (GenBank accession numbers EF014450-EF014452, EF014455 and EF014457EF014461) were manually edited with the BioEdit program (Hall, 1999). In the case of the 16S rRNA gene sequences, isolate identities were established by comparing the sequences obtained with the Ribosomal Database Project and the NCBI databases. Phylogenetic reconstruction for the recA gene was done using seven complete genomes of Bacillus strains reported in the NCBI database. Sequences were aligned using the CLUSTAL_W program (Thompson et al., 1994). Phylogenetic reconstruction for the 16S rRNA and recA genes was done using the neighbour-joining algorithm with Kimura two-parameter distances, as implemented in MEGA3 (Kumar et al., 2004).

Strain $\mathrm{m} 4-4^{\mathrm{T}}$ was subjected to morphological and physiological tests that showed significant differences with respect to other closely related Bacillus species (Table 1). Strain $\mathrm{m} 4-4^{\mathrm{T}}$ grew on only three carbon sources (starch, glycerol and trehalose). Cells were rod-shaped, approximately 0.5$0.7 \mu \mathrm{m}$ in diameter and $1.5-3 \mu \mathrm{m}$ in length after 2 days of cultivation at $37{ }^{\circ} \mathrm{C}$ (Supplementary Fig. S1, available in

\section{Table 1. Differential characteristics of strain $m 4-4^{\top}$ and closely related strains}

Strains: 1 , m4-4 $4^{\mathrm{T}} ; 2$, B. marisflavi JCM $11544^{\mathrm{T}} ; 3$, B. aquimaris JCM $11545^{\mathrm{T}} ; 4$, B. vietnamensis NRIC $0531^{\mathrm{T}}$. The four strains were positive for utilization of starch, glycerol, L-glutamine, citrate, trehalose and fumarate. All strains were negative for nitrate reduction, $\mathrm{H}_{2} \mathrm{~S}$ and urease.

\begin{tabular}{|c|c|c|c|c|}
\hline Characteristic & 1 & 2 & 3 & 4 \\
\hline Spore position ${ }^{\star}$ & C & $\mathrm{S}$ or $\mathrm{C}$ & $\mathrm{C}$ & C \\
\hline Colony colour $\dagger$ & LY & PY & $\mathrm{PO}$ & $\mathrm{O}$ \\
\hline D-Mannose & - & + & - & - \\
\hline Raffinose & - & + & - & - \\
\hline Lactose & - & + & + & + \\
\hline Arabinose & - & + & + & + \\
\hline Dulcitol & - & + & + & + \\
\hline Fructose & - & + & + & + \\
\hline Adonitol & - & + & + & + \\
\hline D-Sorbitol & - & + & + & + \\
\hline L-Rhamnose & - & + & + & + \\
\hline Optimal temperature for growth $\left({ }^{\circ} \mathrm{C}\right)$ & $30-37$ & $30-37$ & $30-37$ & $30-40$ \\
\hline Growth at $45{ }^{\circ} \mathrm{C}$ & - & + & - & + \\
\hline Optimal $\mathrm{pH}$ for growth & $7.0-80$ & $6.0-8.0$ & $6.0-7.0$ & $6.0-8.0$ \\
\hline \multicolumn{5}{|l|}{ Growth at: } \\
\hline $\mathrm{pH} 4.5$ & - & + & - & - \\
\hline pH 9.0 & + & + & - & + \\
\hline \multicolumn{5}{|l|}{$\mathrm{NaCl}$ for growth $(\% \mathrm{w} / \mathrm{v})$ : } \\
\hline Optimum & 5 & 5 & 9 & 5 \\
\hline Maximum & 10 & 10 & 15 & 15 \\
\hline Major cellular fatty acids ( $\%$ of total $) \ddagger$ & $\begin{array}{c}\mathrm{C}_{14: 0}(29.4 \%), \\
\mathrm{C}_{16: 0}(22.3 \%), \\
\mathrm{C}_{18: 1}(15.2 \%)\end{array}$ & $\begin{array}{c}\text { ai-C } \mathrm{C}_{15: 0}(27.7 \%) \\
\mathrm{i}-\mathrm{C}_{15: 0}(22.9 \%) \\
\mathrm{i}-\mathrm{C}_{14: 0}(9.1 \%)\end{array}$ & $\begin{array}{c}\mathrm{i}-\mathrm{C}_{15: 0}(46.9 \%), \\
\text { ai-C } \mathrm{C}_{15: 0}(22.2 \%), \\
\mathrm{i}-\mathrm{C}_{14: 0}(6.5 \%)\end{array}$ & $\begin{array}{c}\text { ai-C } C_{15: 0}(48.3 \%), \\
\text { i-C } C_{15: 0}(16.2 \%), \\
\text { ai-C } C_{17: 0}(13.6 \%)\end{array}$ \\
\hline
\end{tabular}

${ }^{*} \mathrm{C}$, Central; $\mathrm{s}$, subterminal.

†LY, Light yellow; O, orange; PO, pale orange; PY, pale yellow.

$\ddagger \mathrm{i}$, iso; ai, anteiso. 
IJSEM Online). The $\mathrm{G}+\mathrm{C}$ content of $37 \mathrm{~mol} \%$ for strain $\mathrm{m} 4-4^{\mathrm{T}}$ is significantly different from that for $B$. marisflavi (49 $\mathrm{mol} \%$ ) and B. vietnamensis (43-44 $\mathrm{mol} \%$ ), but not from that for B. aquimaris (38 mol\%).

The major cellular fatty acids of strain $\mathrm{m} 4-4^{\mathrm{T}}$ were $\mathrm{C}_{14: 0}$ (29.4\%), $\mathrm{C}_{16: 0}(22.3 \%), \mathrm{C}_{18: 1}(15.2 \%)$ and $\mathrm{C}_{17: 0}(7.9 \%)$. Fatty acids occurring in minor amounts were $\mathrm{C}_{12: 0}$ $(1.3 \%)$, anteiso- $\mathrm{C}_{17: 0}(4.7 \%)$ and anteiso- $\mathrm{C}_{15: 0}(4.8 \%)$ (Supplementary Table S1). Fatty acids profile comparisons between strain $\mathrm{m} 4-4^{\mathrm{T}}$ and other species of the genus Bacillus reveal significant differences (Table 1).

16S rRNA gene sequence similarity between strain $\mathrm{m} 4-4^{\mathrm{T}}$ and type strains of other phylogenetically closely related Bacillus species (B. marisflavi, B. aquimaris and $B$. vietnamensis) ranged from 96.6 to $97.4 \%$. Values obtained in this study meet widely accepted criteria for delineating species in current bacteriology (Stackebrandt \& Goebel, 1994). A $16 S$ rRNA gene-sequence-based neighbour-joining phylogeny analysis revealed that the three different ribosomal operons of strain $\mathrm{m} 4-4^{\mathrm{T}}$ formed a tight and highly supported clade (100\% bootstrap support) nested within a deeper cluster that comprises B. aquimaris, $B$. marisflavi, B. vietnamensis and Bacillus seohaeanensis at a bootstrap confidence level of $87 \%$ (Fig. 1). In addition, a $r e c A$-based neighbour-joining tree also grouped strain $\mathrm{m} 4-4^{\mathrm{T}}$ as a strongly supported monophyletic lineage (Supplementary Fig. S2), which is distinct from the clade comprising B. marisflavi and B. vietnamensis.

Our results show that strain $\mathrm{m} 4-4^{\mathrm{T}}$ can grow in medium containing $\mathrm{NaCl}$ in the range 0.5 to $10 \%(\mathrm{w} / \mathrm{v})$. From these data we concluded that this Bacillus strain is moderately halophilic (Ventosa et al., 1998).

In this study we described a Bacillus isolate using biochemical and genomic data as well as phylogenetic reconstructions involving $16 \mathrm{~S}$ rRNA and recA gene sequences. This approach showed that $\mathrm{m} 4-4^{\mathrm{T}}$ is a member of a distinct group within the genus Bacillus. The strain displayed characteristics typical of Bacillus species, like spore production and low DNA G $+\mathrm{C}$ content (37 mol\%). However, the fatty acid composition for strain $\mathrm{m} 4-4^{\mathrm{T}}$ is completely different from those of other closely related Bacillus species (Supplementary Table S1). Chains $\mathrm{C}_{14}, \mathrm{C}_{16}$, and $\mathrm{C}_{18}$ are characteristic for this novel isolate. Phylogenetic analysis using 16S rRNA gene sequences showed that the novel isolate formed a distinct clade compared with the closely related type strains of $B$. marisflavi (JCM $\left.11544^{\mathrm{T}}\right), B$. aquimaris $\left(\mathrm{JCM} 11545^{\mathrm{T}}\right), B$. vietnamensis (NRIC $0531^{\mathrm{T}}$ ) and B. seohaeanensis (DSM $\left.16464^{\mathrm{T}}\right)$. Phylogenetic reconstruction using $\operatorname{rec} A$ gene sequences also showed that the novel isolate formed a distinct group compared with B. marisflavi JCM $11544^{\mathrm{T}}$ and $B$. vietnamensis strains NRIC $0531^{\mathrm{T}}, 0530,0532$, and 0533. We suggest, on the basis of the data described above, that strain $\mathrm{m} 4-4^{\mathrm{T}}$ should be placed within the genus Bacillus as a representative of a novel species, for which the name Bacillus coahuilensis sp. nov. is proposed.

\section{Description of Bacillus coahuilensis sp. nov.}

Bacillus coahuilensis (co.a.hui.len'sis. N.L. masc. adj. coahuilensis in reference to Coahuila, the state in Mexico where the type strain was collected).

Vegetative cells are rod-shaped, occurring in large chains (Supplementary Fig. S1a), approximately $0.5-0.7 \mu \mathrm{m}$ in diameter by $1.5-3 \mu \mathrm{m}$ in length. Central ellipsoidal endospores are observed in swollen sporangia and are $1.0 \mu \mathrm{m}$ wide and 1.5-1.7 $\mu \mathrm{m}$ long (Supplementary Fig. S1b, c). Colonies on MA are light yellow and $2-5 \mathrm{~mm}$ in diameter after 2 days growth at $37^{\circ} \mathrm{C}$; they are low, convex, circular and slightly irregular. Optimal growth temperature is $30-37{ }^{\circ} \mathrm{C}$ and the maximum growth temperature is $45^{\circ} \mathrm{C}$. Minimum $\mathrm{pH}$ for growth lies between 5.0 and 5.5, the optimum $\mathrm{pH}$ for growth is between 7 and 8 and the maximum $\mathrm{pH}$ for growth is 9 . Acid is produced from glycerol, but not from D-glucose or lactose. Citrate and fumarate can be utilized. Nitrate reduction was not present. $\mathrm{H}_{2} \mathrm{~S}$ and urease are not produced. Does not utilize sucrose, lactose, arabinose, dulcitol, fructose, adonitol, D-sorbitol, salicin, D-mannitol, D-xylose, L-rhamnose and L-glutamine as sole carbon and energy sources. DNA G $+\mathrm{C}$ content of the type strain is $37 \mathrm{~mol} \%$. Halotolerant, growing in $\mathrm{NaCl}$ salt concentration from 0.5 to $10 \%$. The major fatty acids are $\mathrm{C}_{14: 0}, \mathrm{C}_{16: 0}$ and $\mathrm{C}_{18: 1}$. Additionally, based on genome analysis, strain $\mathrm{m} 4-4^{\mathrm{T}}$ showed nine ribosomal operons with three different sequences (Fig. 1).

The type strain, $\mathrm{m} 4-4^{\mathrm{T}}\left(=\right.$ NRRL B- $41737^{\mathrm{T}}=$ CECT $\left.7197^{\mathrm{T}}\right)$, was isolated from a desiccation lagoon in the Cuatro Ciénegas Valley in Coahuila, Mexico.

\section{Acknowledgements}

This research was supported by a CONACyT scholarship to C. R. The project was funded by SEMARNAT/CONACyT and SEP CONACyT (C01-0237/A1 and 44673 Q) to V.S. and L.E. F. We thank Antonio Cruz, Laura Espinosa and José Luis Hernández for specialized technical assistance and Morena Avitia and Miguel Contreras for laboratory work. Special thanks to Alejandro Rooney for incorporating the strains to the NRRL collection and Luisa Falcon and Ana M. Noguez for thoughtful comments and Mark Schneegurt for providing useful bacillus strains.

\section{References}

Alcaraz, L. D., Olmedo, G., Bonilla, G., Cerritos, R., Hernández, G., Cruz, A., Ramírez, E., Putonti, C., Jiménez, B. \& other authors (2008). The genome of Bacillus coahuilensis reveals adaptations essential for survival in the relic of an ancient marine environment. Proc Natl Acad Sci U S A (in press).

Cowan, S. T. \& Steel, K. J. (1965). Manual for the Identification of Medical Bacteria. Cambridge: Cambridge University Press.

Hall, T. A. (1999). BioEdit: a user-friendly biological sequence alignment editor and analysis program for Windows 95/98/NT. Nucleic Acids Symp Ser 41, 95-98.

Istock, C. A., Ferguson, N., Istock, N. L. \& Duncan, K. E. (2001). Geographical diversity of genomic lineages in Bacillus subtilis (Ehrenberg) Cohn sensu lato. Org Divers Evol 1, 179-191. 
Kumar, S., Tamura, K. \& Nei, M. (2004). MEGA3: integrated software for molecular evolutionary genetics analysis and sequence alignment. Brief Bioinform 5, 150-163.

Lane, D. J. (1991). 16S/23S rRNA sequencing. In Nucleic Acid Techniques in Bacterial Systematics, pp. 115-175. Edited by E. Stackebrandt \& M. Goodfellow. Chichester: Wiley.

Lányí, B. (1987). Classical and rapid identification methods for medically important bacteria. Methods Microbiol 19, 1-67.

Lee, J.-C., Lim, J.-M., Park, D.-J., Jeon, C. O., Li, W.-J. \& Kim, C.-J. (2006). Bacillus seohaeanensis sp. nov., a halotolerant bacterium that contains L-lysine in its cell wall. Int J Syst Evol Microbiol 56, 1893-1898.

Lim, J. M., Jeon, C. O., Lee, S. M., Lee, J. C., Xu, L. H., Jiang, C. L. \& Kim, C. J. (2006). Bacillus salarius sp. nov., a halophilic, sporeforming bacterium isolated from a salt lake in China. Int J Syst Evol Microbiol 56, 373-377.

Margulies, M., Elgholm, M., Altman, W. E., Attiya, S., Bader, J. S., Bemben, L. A., Berka, J., Braverman, M. S., Chen, Y. J. \& other authors (2005). Genome sequencing in microfabricated high-density picolitre reactors. Nature 437, 376-380.

Noguchi, H., Uchino, M., Shida, O., Takano, K., Nakamura, L. K. \& Komagata, K. (2004). Bacillus vietnamensis sp. nov., a moderately halotolerant, aerobic, endospore-forming bacterium isolated from Vietnamese fish sauce. Int J Syst Evol Microbiol 54, 2117-2120.

Nunally, B. K. (2005). Analytical Techniques in DNA Sequencing. Boca Raton, FL: Taylor \& Francis CRC Press.

Sacchi, C. T., Whitney, A. M., Mayer, L. W., Morey, R., Steigerwalt, A., Boras, A., Weyant, R. S. \& Popovic, T. (2002). Sequencing of $16 \mathrm{~S}$ rRNA gene: a rapid tool for identification of Bacillus anthracis. Emerg Infect Dis 8, 1117-1123.

Siefert, J. L., Larios-Sanz, M., Nakamura, L. K., Slepecky, R. A., Paul, J. A., Moore, E. R., Fox, G. E. \& Jurtshuk, P., Jr (2000). Phylogeny of marine bacillus isolates from the Gulf of Mexico. Curr Microbiol 41, $84-88$.
Souza, V., Espinosa-Asuar, L., Escalante, A. E., Eguiarte, L., Farmer, J., Forney, L., Lloret, L., Rodriguez-Martínez, J. M., Soberon, X. \& other authors (2006). An endangered oasis of aquatic microbial diversity in the Chihuahuan desert. Proc Natl Acad Sci U S A 103, 6565-6570.

Stackebrandt, E. \& Goebel, B. M. (1994). Taxonomic note: a place for DNA-DNA reassociation and 16S rRNA sequence analysis in the present species definition in bacteriology. Int J Syst Bacteriol 44, 846-849.

Stackebrandt, E., Frederiksen, W., Garrity, G. M., Grimont, P. A. D., Kämpfer, P., Maiden, C. J. M., Nesme, X., Rosselló-Mora, R., Swings, J. \& other authors (2002). Report of the ad hoc committee for the reevaluation of the species definition in bacteriology. Int J Syst Evol Microbiol 52, 1043-1047.

Thompson, J. D., Higgins, D. G. \& Gibson, T. J. (1994). CLUSTAL W: improving the sensitivity of progressive multiple sequence alignment through sequence weighting, position-specific gap penalties and weight matrix choice. Nucleic Acids Res 22, 4673-4680.

Ventosa, A., Nieto, J. \& Oren, A. (1998). Biology of moderately halophilic aerobic bacteria. Microbiol Mol Biol Rev 62, 504-544.

Yoon, J.-H. \& Oh, T.-K. (2005). Bacillus litoralis sp. nov., isolated from a tidal flat of the Yellow Sea in Korea. Int J Syst Evol Microbiol 55, 1945-1948.

Yoon, J. H., Kim, I. G., Kang, K. H., Oh, T. K. \& Park, Y. H. (2003). Bacillus marisflavi sp. nov. and Bacillus aquimaris sp. nov., isolated from sea water of a tidal flat of the Yellow Sea in Korea. Int J Syst Evol Microbiol 53, 1297-1303.

Yoon, J.-H., Kim, I.-J., Kang, K. H., Oh, T.-K. \& Park, Y.-H. (2004). Bacillus hwajinpoensis sp. nov. and an unnamed Bacillus genomospecies, novel members of Bacillus rRNA group 6 isolated from sea water of the East Sea and the Yellow Sea in Korea. Int J Syst Evol Microbiol 54, 803-808.

Zeigler, D. R. (2003). Gene sequences useful for predicting relatedness of whole genomes in bacteria. Int J Syst Evol Microbiol 53, 1893-1900. 